\title{
Efficacy and safety of new direct oral anticoagulants in chronic kidney disease: AHA 2019 updated guidelines and review of the literature
}

\author{
Hubert Stępak ${ }^{1}$, Zbigniew Krasiński ${ }^{1}$, Andrzej Jawieñ ${ }^{1}$, Navid Ahmadi ${ }^{1}$, Adam Lipowski ${ }^{2}$, Michał Stanisic ${ }^{1}$ \\ ${ }^{1}$ Department of Vascular and Endovascular Surgery, Angiology and Phlebology, Poznan University of Medical Sciences, Poznan, \\ Poland \\ 2Department of General Surgery, Nowa Sol Hospital, Poland
}

Kardiochir Torakochir Pol 2019; 16 (4): 194-200

\begin{abstract}
Direct oral anticoagulants (DOACs) are the drug of choice for the treatment of atrial fibrillation-associated systemic embolism and reducing the risk of strokes in chronic kidney disease (CKD) patients. DOACs have fewer drug-to-drug interactions as well as fewer side effects, compared to warfarin. This article compiled up-to-date research on the use of DOACs in CKD patients, taking the AHA 2019 guidelines into consideration. The aim of this article was to compare the efficacy and safety of DOACs with warfarin and to assess whether DOACs are a better alternative to warfarin. Among DOACs, apixaban has been shown to have the best outcome compared to other DOACs. As a result, the AHA 2019 updated guidelines have recommended warfarin and apixaban to be the first line agents for CKD patients. This review concluded that DOACs are better option in patients with mild to moderate CKD and excluding apixaban other DOACs are not indicated in patients with $\mathrm{CrCl}<25 \mathrm{ml} / \mathrm{min}$.
\end{abstract}

Key words: direct oral anticoagulants, chronic kidney disease.

\section{Introduction}

A number of pivotal phase-3 trials of direct oral anticoagulants (DOACs) have been shown to yield more desirable results in preventing embolism in the population with atrial fibrillation (AFib) and decreasing stroke incidence, in addition to reducing bleeding [1]. However, all of these studies were carried out in subjects with a glomerular filtration rate (GFR) of $>30 \mathrm{ml} / \mathrm{min}$ and patients on dialysis or those with advanced chronic kidney disease (CKD) were excluded from their studies [1]. CKD is widely defined as a GFR $<60 \mathrm{ml}$ min for a minimum of 3 months, and has varying prevalence in different regions, being highly associated with aging populations.

Chronic kidney disease and end stage renal disease (ESRD) remains a significant health problem and a rapid

\section{Streszczenie}

Nowe doustne antykoagulanty (NOAC) są stosowane w profilaktyce udaru mózgu lub zatorowości obwodowej u pacjentów z migotaniem przedsionków i przewlekłą chorobą nerek (PChN). NOAC odznaczają się mniejszym odsetkiem interakcji oraz mniejszym odsetkiem skutków ubocznych w porównaniu z warfaryną. Artykut stanowi podsumowanie dotychczasowych publikacji poświęconych tej tematyce, w tym wytycznych American Heart Association (AHA) z 2019 r. Celem artykułu jest porównanie skuteczności i bezpieczeństwa NOAC z warfaryną i ocena, czy NOAC są lepszym wyborem niż warfaryna. Wykazano, że wśród wszystkich preparatów NOAC najlepszymi parametrami cechuje się epiksaban. W związku z tym zaktualizowane wytyczne AHA z 2019 r. zalecają warfarynę i apiksaban w PChN. Ponadto NOAC stanowią lepszą opcję leczenia u pacjentów z łagodną i umiarkowaną PChN i wyłączając apiksaban, inne NOAC nie są wskazane u pacjentów z $\mathrm{CrCl}<25 \mathrm{ml} / \mathrm{min}$.

Słowa kluczowe: nowe doustne antykoagulanty, przewlekła choroba nerek.

rise has been reported from the late 1990s to 2019. The current prevalence of CKD in the United State (US) as of 2018 is $15 \%$, which is up by almost $3 \%$ since 2015 [2]. These patients are at a higher risk of non-valvular AFib as well as an increased incidence of haemorrhage. This bleeding tendency is due to uraemia-induced platelet dysfunction and abnormalities in subendothelial interaction, with increased procoagulation and reduced endogenous anticoagulation [3]. Patients on haemodialysis have an added risk of bleeding due to the administration of heparin, repeated dialysis membrane interaction, vascular access cannulation and increased blood pressure. The introduction of four new DOAC, namely edoxaban, apixaban, rivaroxaban and dabigatran, has broadened the options of anticoagulation in patients with CKD and AFib. These agents have been shown to have

Address for correspondence: Hubert Stępak MD, Department of Vascular and Endovascular Surgery, Angiology and Phlebology,

Poznan University of Medical Sciences, 1/2 Długa St, 61-848 Poznan, Poland, e-mail: hstepak@gmail.com

Received: 26.09.2019, accepted: 12.11.2019. 
decreased the frequency of bleeding, embolism, and risk of stroke, and have widely been prescribed for patients with CKD, ESRD and calciphylaxis [4].

The prevalence of AFib is directly proportional to the kidney function, with an increase in AFib as the GFR decreases. The incidence of AFib is as much as $15 \%$ higher in CKD patients compared to healthy age-matched control groups [5]. The most recent 2019 American Heart Association (AHA) guideline for the management of patients with AFib and CKD has been modified. Apixaban, dabigatran and rivaroxaban are approved to be used for patients with $\mathrm{CrCl}<15 \mathrm{ml} / \mathrm{min}, \mathrm{CrCl} 15-30 \mathrm{ml} / \mathrm{min}$, and $\mathrm{CrCl}<50 \mathrm{ml} / \mathrm{min}$ respectively. All of these medications have a $l \mathrm{lb}$ (Benefit $\geq$ Risk) Class of Recommendation (COR) with 'B-R' (Moderate quality) as Level of Evidence (LOE). While the use of DOACs such as rivaroxaban, dabigatran or edoxaban is not recommended in patients with AFib and ESRD, LOE is updated from 'Limited data' to 'Expert Opinion' with COR of III (Benefit = Risk) [6].

Despite the lack of evidence showing the efficiency of DOACs in large-scale trials and the above updated recommendations, many physicians are still prescribing these drugs to their patients [7]. This is concerning because all of these agents rely on kidneys for excretion. Chan et al. reported that around $12 \%$ of patients on dialysis with AFib and $24 \%$ of patients with advanced CKD were prescribed DOACs. Apixaban was the most common DOACs at $10.4 \%$ in CKD and $10.5 \%$ in dialysis patients $(n=102,504$ and $n=140,918)$ respectively [1]. Oral anticoagulants such as warfarin are not largely prescribed, even with evidence of AFib associated thrombo-embolism in CKD patients, in fear of excessive bleeding complications [8]. Nonetheless, warfarin, a vitamin $\mathrm{K}$ antagonist (VKA), is still the best choice of anticoagulant in AFib patients. A large clinical study of warfarin in 2014 showed protection from cardiovascular events without any increased risk of bleeding [9]; however, Nochaiwong in 2016 reported that warfarin actually increased the frequency of bleeding and did not reduce ischaemic events, strokes or the number of deaths [10].

This review article summarises the up-to-date available pharmacology of commonly used DOACs, and their efficacy in preventing stroke as well as reducing bleeding risks. This article focuses mainly on patients suffering from AFib and CKD. In addition, the use of DOACs in advanced kidney disease and dialysis will be discussed before determining their use in these particular subjects. This article will also concisely review the AHA 2019 guidelines and the various changes that have occurred since 2014.

\section{Pharmacokinetics of drugs in CKD}

The ability of the kidney to remove uric acid from the body decreases as the GFR declines, resulting in an increase in uraemia. Uraemia has a negative effect on pharmacokinetics (PK), by impairing plasma protein binding and as a result increasing the drug levels in the body. Renal excreted drugs are cleared through the glomerulus and rarely by tubular secretion. Therefore, reduced GFR results in an increased half time and increased level of drug, which leads to toxicity from supra-therapeutic levels in the body [10] Consequently, the area under the curve (AUC) increases, requiring an appropriate dose adjustment.

In clinical practice, dosing of anticoagulants is estimated using a formula and one single serum creatinine level. In contract, the Cockcroft-Gault formula is used to calculate renal function when DOACs are used. This method has been shown to overestimate by $10-40 \%$; therefore, novel equations such as 'Modification of Diet in Renal Disease', and 'Chronic Kidney Disease Epidemiology Collaboration' have consistently proved to be more precise [11].

\section{Warfarin}

Warfarin is a VKA drug, which was approved to be used as an anticoagulant in the mid nineteenth century. Warfarin is minimally dependent on renal excretion as it is $99 \%$ bound to plasma proteins and its elimination is through the hepatic metabolism. The same property makes warfarin non-dialyzable and drug-to-drug interaction should be carefully managed as these patients are on a multi-drug regimen. Reversal of warfarin with low doses of vitamin $\mathrm{K}$ or fresh-frozen plasma, as well as wide availability and low cost, makes its use desirable in everyday life [12]. Limdi et al. in their study concluded that CKD patients are at an increased risk of bleeding and a dose reduction is required (10\% in patients with GFR of 30-59) [13]. Despite a black box warning of the use of warfarin by the FDA in patients with CKD, as it is known to increase haemorrhage, it is still widely used [7]. In fact, the AHA 2019 updated guideline still recommends warfarin as the first-choice treatment in treating AFib patients suffering from CKD, followed by the second choice of apixaban [6]. The use of enoxaparin, among other low molecular weight heparins ( $\mathrm{LMWH})$, has been shown to be contraindicated in patients with CKD stage 4-5 due to the accumulation of the drug and the increased risk of major bleeding [14].

\section{Direct oral anticoagulants (DOACs)}

Currently, to our knowledge, the FDA has approved four DOACs for the prevention of AFib associated thromboembolism; these are: dabigatran, apixaban, edoxaban and rivaroxaban. Thorough management of these DOACs, and dosing regulation, adverse side effects and reversal agents have become paramount in clinical practice. Studies have been carried out to tackle these issues and some of the antidotes of DOACs are shown in Table I $[7,15,16]$.

Appropriate DOAC dose reductions rely on the level of renal function and currently approved doses of these regimens in CKD I-III in Europe are shown in Table II [17, 18]. DOACs in many studies have proved to be more efficient and safer than VKA when the GFR is $>60 \mathrm{ml} / \mathrm{min}$. In addition, patients on DOACs with a $\mathrm{CrCl} 30-50 \mathrm{ml} / \mathrm{min}$ were shown to have fewer bleeding complications and had similar effectiveness compared to warfarin. However, the use of VKA surpasses DOACs in individuals with GFR less than $30 \mathrm{ml}$ min, especially dabigatran, which has the highest percent- 
Efficacy and safety of new direct oral anticoagulants in chronic kidney disease: AHA 2019 updated guidelines and review of the literature

Table I. DOACs and their reversal antidotes

\begin{tabular}{lcccc} 
Reversal agent & Dabigatran & Apixaban & Edoxaban & Rivaroxaban \\
Specific antidote & Idarucizumab & Andexanet alfa & - & - \\
\hline Fresh frozen plasma & No & Yes & Yes & Yes \\
\hline Factor VIII inhibitor bypass & Yes & Yes & Yes & Yes \\
\hline Haemodialysis & Yes & No & No & No \\
\hline
\end{tabular}

Table II. Properties of different DOACs and drug regimens in patients suffering from CKD

\begin{tabular}{lcccccc} 
Drug & $\begin{array}{c}\text { Kidney } \\
\text { elimination (\%) }\end{array}$ & $\begin{array}{c}\text { Peak } \\
\text { effect }[\mathrm{h}]\end{array}$ & \multicolumn{5}{c}{ Renal function $(\mathrm{CrCl}[\mathrm{ml} / \mathrm{min}])$} \\
\cline { 5 - 7 } Dabigatran & 80 & $1-3$ & $220 \mathrm{mg}$ twice/day & $150 \mathrm{mg}$ once/day & Not indicated & Not indicated \\
\hline Apixaban & 25 & $1-2$ & $2.5 \mathrm{mg}$ twice/day & $2.5 \mathrm{mg}$ twice/daily & Use with caution & Not recommended \\
\hline Edoxaban & 35 & $1-2$ & $60 \mathrm{mg}$ once/day & $30 \mathrm{mg}$ once/day & $30 \mathrm{mg}$ once daily & Not recommended \\
\hline Rivaroxaban & 33 & $2-4$ & $10 \mathrm{mg}$ once/day & $10 \mathrm{mg}$ once/day & Use with caution & Not indicated \\
\hline
\end{tabular}

age renal elimination [19]. Numerous studies have shown that DOACs significantly reduce the risk of embolism, strokes and intracranial bleeding events while increasing $\mathrm{Gl}$ bleeding compared to VKA use (Table III) [20-23]. However, a study published by Jun et al. did not show any association of GI bleeding with the use of DOACs [24].

\section{Direct thrombin inhibitor drugs Dabigatran}

Dabigatran is a direct thrombin inhibitor and dabigatran etexilate at $150 \mathrm{mg}$ twice daily is the first DOAC to be approved by the FDA for prevention of embolisms and strokes for population with $\mathrm{CrCl}>30 \mathrm{ml} / \mathrm{min}$. This drug is coated with a tartaric acid core, which augments bioavailability at a lower $\mathrm{pH}$ and this core is associated with causing dyspepsia and Gl bleeding [25]. Prothrombin time (PT) has been shown to be better than APTT in measuring the concentration of dabigatran, but it does not differentiate between sub-therapeutic and therapeutic doses [26]. Therefore, the ecarin-clotting time (derived when ecarin cleaves prothrombin to meizothrombin) has been shown to be highly sensitive and strongly correlates with dabigatran concentration. A parallel-group study on the PK and PD of dabigatran in 23 patients with CKD showed a higher area under the plasma concentration-time curve values in subjects with $\mathrm{CrCl}$ 50-80 $\mathrm{ml} / \mathrm{min}$ (1.5 times higher), 30-50 $\mathrm{ml} / \mathrm{min}$ (3.2 times higher) and $<30 \mathrm{ml} / \mathrm{min}$ (6.3 times higher) compared to healthy individuals. In addition, the time of drug elimination increased two fold from 14 hours to 28 hours in patients with severe kidney disease [27].

In the Randomized Evaluation of Long-Term Anticoagulation Therapy (RE-LY) study, 6,015 patients were given low-dose (110 mg) dabigatran, 6,076 subjects were treated with a higher dose $(150 \mathrm{mg})$ twice daily and 6,022 were given warfarin. After 2 years of follow-up, they observed a lower incidence of strokes, MI, PE, hospitalisation, vascular deaths and major haemorrhages in subjects treated
Table III. Large-scale clinical studies of DOACs and their outcome in terms of stroke and GI bleeding compared to warfarin use

\begin{tabular}{lccc} 
Study & $\begin{array}{c}\text { Sample } \\
\text { size }\end{array}$ & $\begin{array}{c}\text { HR }(95 \% \mathrm{Cl}) \\
\text { of stroke }\end{array}$ & $\begin{array}{c}\text { HR }(95 \% \mathrm{CI}) \\
\text { of Gl bleeding }\end{array}$ \\
\hline Lauffenburger [20] & 6727 & 0.76 & 1.52 \\
\hline Graham [21] & 134,414 & 0.80 & 1.28 \\
\hline Romanelli [22] & 348750 & 0.92 & 1.23 \\
\hline Patel [23] & 7111 & 0.85 & 3.15 \\
\hline
\end{tabular}

with dabigatran compared to warfarin. The results of the study are summarised in Table IV [28, 29].

Warfarin was the only drug of choice in preventing embolisms in AFib patients preceding the RE-LY study. However, the RE-LY study demonstrated the 150-mg dabigatran regimen to be significantly superior in terms of low bleeding and stroke rates in comparison to warfarin. Additional studies have shown that the risk of systemic embolism increases as the $\mathrm{CrCl}$ decreases in subjects given dabigatran [30]. In the RE-LY study, patients with severe kidney disease were excluded; therefore the FDA carried out a study on 3,343 subjects with a GFR of $30-50 \mathrm{ml} / \mathrm{min}$. They concluded that the high dosage of dabigatran had a greater benefit with regards to reducing strokes and systemic embolisms, as well as low bleeding in comparison to $110 \mathrm{mg}$ dosage [31]. Subsequently, the FDA approved a $150 \mathrm{mg}$ dose of dabigatran to be used in patients with $\mathrm{CrCl} 30-50 \mathrm{ml} / \mathrm{min}$, and $75 \mathrm{mg}$ twice daily in $\mathrm{CrCl} 15-30 \mathrm{ml} / \mathrm{min}$, to lower the likelihood of embolisms and strokes [31]. A model simulation confirmed that $75 \mathrm{mg}$ daily dabigatran lowered the steadystate peak by $31 \%$ and trough levels by $42 \%$ compared to the higher dose (150 mg) twice a day in CKD patients [31].

One session of haemodialysis ( 4 hours) has been shown to remove as much as $60 \%$ of dabigatran, making it the only DOAC to be removed by this method. Therefore, patients undergoing haemodialysis are not recommended dabigatran for anticoagulation [27]. 
Table IV. Treatment regimens and their outcome in the RE-LY study

\begin{tabular}{lcc} 
Outcome & Warfarin versus low dose dabigatran & Warfarin versus high dose dabigatran \\
Systemic emboli or stroke (\%) & 1.69 vs. 1.53 & 1.69 vs. 1.11 \\
\hline Relative risk $(95 \% \mathrm{Cl})$ & $0.91(0.74-1.11)$ & $0.66(0.53-0.82)$ \\
\hline$P$-value & $<0.001$ & $<.001$ \\
\hline Stroke $(\%)$ & 1.6 vs. $1.4(p=0.41)$ & 1.6 vs. $1.0(p<0.001)$ \\
\hline Cardiac ischaemia (\%) & 0.53 vs. 0.72 & 0.53 vs. 0.74 \\
\hline Pulmonary embolism (\%) & 0.09 vs. $0.12(p=0.56)$ & 0.09 vs. $0.09(p=0.21)$ \\
\hline Hospitalization $(\%)$ & 20.8 vs. $19.4(p=0.003)$ & 20.8 vs. $20.2(p=0.34)$ \\
\hline Death related to vessels (\%) & 2.69 vs. $2.43(p=0.21)$ & 2.28 vs. $2.69(p=0.04)$ \\
\hline Major haemorrhage $(\%)$ & 3.36 vs. $2.71(p=0.003)$ & 3.36 vs. $3.11(p=0.31)$ \\
\hline Mortality $(\%)$ & 4.13 vs. $3.75(p=0.13)$ & 4.13 vs. $3.64(p=0.051)$ \\
\hline
\end{tabular}

Table V. Comparison of clinical outcome of patients treated with apixaban and warfarin

\begin{tabular}{lccccc} 
Parameter & Apixaban & Warfarin & HR & $95 \% \mathrm{Cl}$ & $P$-value \\
Major bleeding (\% per-year) & 2.13 & 3.09 & 0.69 & $0.60-0.80$ & $<0.001$ \\
\hline All-cause mortality (\% per-year) & 3.52 & 3.94 & 0.89 & $0.80-0.99$ & $<0.047$ \\
\hline Haemorrhagic stroke (\% per-year) & 0.24 & 0.47 & 0.51 & $0.35-0.75$ & 0.001 \\
\hline Ischaemic stroke (\% per-year) & 0.97 & 1.05 & 0.92 & $0.74-1.13$ & 0.42 \\
\hline
\end{tabular}

\section{Factor Xa inhibitors}

\section{Apixaban}

In the ARISTOTLE trial, apixaban was compared with warfarin in over 18,000 patients suffering from AFib with one extra risk factor of stroke. The results of the study are summarised in Table V. They established apixaban to be significantly better compared to warfarin in terms of lowering mortality, lowering bleeding and preventing strokes or systemic emboli formation [32]. Consequently, the FDA approved the use of apixaban $(2.5 \mathrm{mg})$ twice a day for patients who are either less than $60 \mathrm{~kg}$, or aged greater than 80 years old and with creatinine of $\leq 1.5 \mathrm{mg} / \mathrm{dl}$. However, in 2014 the dosage for patients suffering from ESRD or those undergoing dialysis was amended. For these patients $5 \mathrm{mg}$ twice daily was suggested, unless they were either $\leq 60 \mathrm{~kg}$ or age $\geq 80$ years old, in which case $2.5 \mathrm{mg}$ twice per day is still used [1]. A double-blinded control trial found that apixaban had 55\% lower incidence of embolism compared to aspirin for patients who tried and failed warfarin treatment [33].

The ARISTOTLE randomised controlled clinical trial, however, excluded subjects with advanced CKD and ESRD. Wang et al., in a parallel group single-dose study, compared 8 haemodialysis patients with 8 healthy patients. They found that patients with ESRD off haemodialysis had a $10 \%$ decrease in Cmax and 36\% increase in AUC compared to healthy individuals who were given $5 \mathrm{mg}$ apixaban. Also ESRD patients undergoing haemodialysis had a reduction in apixaban AUC and $\mathrm{Cmax}$ of $14 \%$ and $13 \%$ respectively [34].

Another open-labelled study of apixaban tolerance and safety at $10 \mathrm{mg}$ single dose showed that AUC increased to almost $45 \%$ in subjects with GFR $<15$ in comparison to healthy patients with normal renal function [35]. Therefore, these studies suggest that current dosing for apixaban could increase drug levels by up to $45 \%$ in ESRD patients. Despite all these studies the use of apixaban is recommended in the 2019 AHA guidelines in patients with advanced CKD [6].

\section{Edoxaban}

Edoxaban is the most recent FDA approved DOAC after a trial that confirmed edoxaban non-inferiority compared to VKA in patients with AFib. ENGAGE AF-TIMI 48, a randomised controlled study of over 21,000 patients, compared two different dose regimens of edoxaban and warfarin in terms of preventing systemic embolism and strokes. As with the RE-LY study, patients with $\mathrm{CrCl}<30 \mathrm{ml} / \mathrm{min}$ were also excluded; however, those with a $\mathrm{CHA}_{2} \mathrm{DS}_{2}-\mathrm{VAS}_{\mathrm{C}}$ score of $>2$ were included in the ENGAGE AF-TIMI trial [36]. The results of the study are summarised in Table VI.

Table VI. Comparison of warfarin with $30 \mathrm{mg}$ and $60 \mathrm{mg}$ of edoxaban

\begin{tabular}{lcccc} 
Outcome (bleeding) & \multicolumn{2}{c}{ Warfarin vs. 30 mg edoxaban } & \multicolumn{2}{c}{ Warfarin vs. 60 mg edoxaban } \\
\cline { 2 - 5 } Stroke & \% People per year & HR $(95 \% \mathrm{Cl})$ & \% People per year & HR $(95 \% \mathrm{Cl})$ \\
\hline Gl bleeding & 0.85 vs. 0.26 & $0.30(0.21-0.43)$ & 0.85 vs. 0.39 & $0.47(0.34-0.63)$ \\
\hline Life-threatening bleeding & 1.23 vs. 0.82 & $0.67(0.53-0.83)$ & 1.23 vs. 1.51 & $1.23(1.02-1.50)$ \\
\hline Fatal & 0.78 vs. 0.25 & $0.32(0.23-0.46)$ & 0.78 vs. 0.40 & $0.51(0.38-0.70)$ \\
\hline
\end{tabular}


Table VII. Comparison of four DOACs and their associated incidence of stroke and bleeding

\begin{tabular}{lcccc}
$\mathrm{CrCl}<50 \mathrm{ml} / \mathrm{min}$ & Dabigatran & Apixaban & Edoxaban & Rivaroxaban \\
$\begin{array}{l}\text { Hazard ratio } \\
\text { of stroke }\end{array}$ & 0.56 & 0.79 & 0.87 & 0.88 \\
\hline $\begin{array}{l}\text { Hazard ratio } \\
\text { of major bleeding }\end{array}$ & 1.01 & 0.50 & 0.76 & 0.98 \\
\hline
\end{tabular}

In summary, both $30 \mathrm{mg}$ and $60 \mathrm{mg}$ of edoxaban were non-inferior to VKA in terms of efficacy and prevention of strokes. This study was followed by a post hoc analysis on 1,202 subjects with GFR $<30 \mathrm{ml} / \mathrm{min}$, which illustrated lower frequency of strokes as well as less major bleeding in subjects treated with edoxaban compared to warfarin [1]. A further study by Korestsune et al. compared 50 patients $(\mathrm{CrCl} 15-30$ $\mathrm{ml} / \mathrm{min}$ ) taking $15 \mathrm{mg}$ of edoxaban to 22 and 21 patients with normal renal receiving 30 or $60 \mathrm{mg}$ of edoxaban respectively. The rate of bleeding was comparable in all three treatments: $20.7 \%$ bleeding (30 $\mathrm{mg}$ ) and $23.8 \%$ bleeding in patients receiving $60 \mathrm{mg}$ of edoxaban. They concluded that administering $15 \mathrm{mg}$ to patients with severe CKD has similar safety and efficacy compared to normal or mild renal impairment [37].

Surprisingly, subjects with $\mathrm{CrCl}>95 \mathrm{ml} / \mathrm{min}$ proved to have a higher risk of stroke when treated with edoxaban compared to warfarin $(\mathrm{HR}=2.16,95 \% \mathrm{Cl}: 1.17-3.07)$ due to a decrease in plasma drug concentration [38]. The kidneys clear around $50 \%$ of edoxaban and a single session of dialysis cleans only $9 \%$ of the total drug.

\section{Rivaroxaban}

Rivaroxaban is a factor Xa inhibitor, also used for the prevention of strokes and systemic embolisms in patients with AFib. The ROCKET AF randomised trial of $>14,000$ patients suffering from AFib and having a $\mathrm{CHA}_{2} \mathrm{DS}_{2}-\mathrm{VAS}_{\mathrm{C}} \geq 2$ with $\mathrm{CrCl}$ $>30 \mathrm{ml} / \mathrm{min}$ demonstrated $20 \mathrm{mg}$ rivaroxaban once a day to be non-inferior to VKA at reducing strokes and embolisms [25]. The dosage decreased to $15 \mathrm{mg}$ daily for subjects with $\mathrm{CrCl} 30-50 \mathrm{ml} / \mathrm{min}$. Nonetheless, there was no difference in the outcome with reduced dosage or $20 \mathrm{mg}$ compared to warfarin [39]. In addition, preventing stroke in patients with $\mathrm{CrCl} 30-50 \mathrm{ml} / \mathrm{min}$ and those with > 50 was very similar: $\mathrm{HR}=0.85,95 \% \mathrm{Cl}: 0.16-1.08$ for $\mathrm{CrCl} 50-80 \mathrm{ml} / \mathrm{min}$ and $\mathrm{HR}=0.88,95 \% \mathrm{Cl}: 0.65-1.19$ for patients with $\mathrm{CrCl} 30-50 \mathrm{ml}$ min [39]. These results were further reinforced by DeVriese et al., who established that patients with ESRD given $10 \mathrm{mg}$ and healthy patients given $20 \mathrm{mg}$ had similar AUCs [40]. Conversely, other studies oppose this and reported an increase of over $5 \%$ in AUC in patients with ESRD treated with a $15 \mathrm{mg}$ dose.

A further PK/PD study demonstrated that rivaroxaban is accumulated in patients with ESRD and an increased systemic exposure therefore requires a dose reduction. The FDA and AHA/ACC/HRS have not recommended rivaroxaban in patients undergoing dialysis, and it has been shown to be poorly cleared by haemodialysis [6].

The hazard ratio (HR) of strokes and other major bleeding using four DOACs compared to warfarin is shown in
Table VII. It is clear that all DOACs are significantly more effective in reducing strokes and other major bleeding in comparison to warfarin. Apixaban yields the most desirable result in comparison to others.

\section{The AHA updated 2019 guideline and the use of DOACS}

The use of anticoagulants started in 1990s after the SPAF trial showed warfarin as the gold standard in preventing stroke in AFib patients. However, warfarin has many adverse effects, such as bleeding complications and ischaemic strokes, owing to the narrow therapeutic margin. Numerous randomised trials of DOACs, including RE-LY, ENGAGE AF-TIMI 48, ARISTOTLE, and ROCKET AF, have shown favourable results both in systemic embolization and stroke risk reduction compared to warfarin.

The new guideline added edoxaban for people with AFib and $\mathrm{CHA}_{2} \mathrm{DS}_{2}-\mathrm{VAS}_{\mathrm{C}} \geq 2$, while warfarin, dabigatran, apixaban and rivaroxaban remained the same as the 2014 guideline [6]. If oral anticoagulation is indicated in patients, the 2019 AHA guideline recommends warfarin as the first line treatment for those with $\mathrm{CrCl} \leq 15 \mathrm{ml} / \mathrm{min}$ or those undergoing dialysis, followed by apixaban as the second choice of DOAC [6]. The AHA 2019 guideline recommends reduced doses of apixaban for patients with GFR $\geq 15$, use of dabigatran for $\mathrm{CrCl} 15-30 \mathrm{ml} / \mathrm{min}$, rivaroxaban for GFR < 50 and finally edoxaban for GFR 15-50, with an increased $\mathrm{CHA}_{2} \mathrm{DS}_{2}-\mathrm{VAS}_{\mathrm{C}}$ score $[6,36]$.

The updated guideline suggests that there is no benefit in using dabigatran, edoxaban or rivaroxaban in ESRD or for patients on dialysis. Moreover, the use of dabigatran is labelled as harmful for those with a artificial heart valve, regardless of the kidney function $[6,29]$. Most DOACs have been shown to be either superior or non-inferior to VKA in reduction of thrombo-embolism in patients with AFib [23, $32,36]$. A progressive meta-analysis is underway comparing individual DOACs to one another and it is expected to increase in the near future. DOACs such as rivaroxaban and dabigatran have shown promising results with a decreased risk of adverse renal outcome compared to warfarin in patients with AFib. There are limited studies on drug interaction with DOACs and therefore well-designed trials are required to evaluate bleeding risk and their efficacy [6]. Likewise with warfarin there are some commercial assays to measure DOAC serum levels, but there is no set reference range that could show a safe dosage in terms of efficacy in clinical outcome [6]. New studies led the AHA to recommend idarucizumab for the reversal of dabigatran and andexanet for rivaroxaban reversal in their 2019 updated guidelines Table I $[6,16]$.

\section{Conclusions}

DOACs are increasingly used in patients with kidney disease because they are more convenient and have improved pharmacological properties, have rapid action and have fewer adverse effects compared to warfarin. Their growing use calls for better understanding of their phar- 
macokinetics and pharmacodynamics in patients with declining GFR. The risks and benefits of the FDA approved and the off-label DOACs are different in CKD and ESRD patients. There is limited support with regards to efficacy and safety of DOACs in patients with $\mathrm{CrCl} \leq 30 \mathrm{ml} / \mathrm{min}$ or ESRD, due to adverse outcomes and hospitalisation. Almost every study excluded patients on dialysis and with $\mathrm{CrCl} \leq 30 \mathrm{ml} /$ min. Thus, deciding on the most efficient and safe DOAC agent is difficult in these patients and warfarin is still the best agent in this population. Patients with complications of warfarin are recommended to use apixaban with a corrected dose. More data are required on dabigatran, edoxaban and rivaroxaban for those with ESRD and for those on dialysis.

\section{Disclosure}

The authors report no conflict of interest.

\section{References}

1. Chan KE, Giugliano RP, Patel MR, Abramson S, Jardine M, Zhao S, Perkovic V, Maddux FW, Piccini JP. Nonvitamin K anticoagulant agents in patients with advanced chronic kidney disease or on dialysis with AF. J Am Coll Cardiol 2016; 67: 2888-2899.

2. Usrds.org. (2019). USRDS Home Page. [online] Available at: https://www. usrds.org/Default.aspx [Accessed 17 March 2019].

3. Harenberg J, Hentschel VA, Du S, Zolfaghari S, Kramer R, Weiss C, Kramer BK, Wehling M. Anticoagulation in patients with impaired renal function and with haemodialysis. Anticoagulant effects, efficacy, safety, therapeutic options. Hamostaseologie 2015; 35: 77-83.

4. King BJ, El-Azhary RA, McEvoy MT, Shields RC, McBane RD, McCarthy JT, Davis MDP. Direct oral anticoagulant medications in calciphylaxis. Int J Dermatol 2017; 56: 1065-1070.

5. Olesen JB, Lip GY, Kamper AL, Hommel K, Kober L, Lane DA, Lindhardsen J, Gislason GH, Torp-Pedersen C. Stroke and bleeding in atrial fibrillation with chronic kidney disease. N Engl J Med 2012; 367: 625-635.

6. January CT, Wann LS, Calkins H, Cigarroa JE, Cleveland JC, Ellinor PT, Ezekowitz MD, Field ME, Furie KL, Heidenreich PA, Murray KT, Shea JB, Tracy CM, Yancy CW. 2019 AHA/ACC/HRS Focused Update of the 2014 AHA/ ACC/HRS Guideline for the Management of Patients With Atrial Fibrillation A Report of the American College of Cardiology/American Heart Association Task Force on Clinical Practice Guidelines and the Heart Rhythm Society. Circulation 2019; 139: e125-e151.

7. Hart RG, Eikelboom JW, Brimble KS, McMurtry MS, Ingram AAH. Stroke prevention in atrial fibrillation patients with chronic kidney disease. Can J Cardiol 2013; 29 (Suppl): S71-S78.

8. You J, Singer DE, Howard PA, Lane DA, Eckman MH, Fang MC, Hylek EM, Schulman S, Go AS, Hughes M, Spencer FA, Manning WJ, Halperin JL, Lip GYH. Antithrombotic therapy for atrial fibrillation: antithrombotic therapy and prevention of thrombosis, 9th ed: Amerian College of Chest Physicians evidence-based clinical practice guidelines. Chest 2012; 141 (2 Suppl): e531Se575S.

9. Bonde AN, Lip GY, Kamper AL, Hansen PR, Lamberts M, Hommel K, Hansen ML, Gislason GH, Torp-Pedersen C, Olesen JB. Net clinical benefit of antithrombotic therapy in patients with atrial fibrillation and chronic kidney disease: a nationwide observational cohort study. J Am Coll Cardiol 2014; 64: 2471-2482

10. Inker LA, Perrone RD. Assessment of kidney function. UpToDate. Available at: http://www.uptodate.com/contents/assessment-of-kidney-function?source $=$ search_result $\&$ search $=$ estimation + of $+g$ fr\&selected Title $=6 \sim 150 \#$ H20659776. Accessed March 17, 2019.

11. Pfeffer MA, Burdmann EA, Chen CY, Cooper ME, de Zeeuw D, Eckardt KU, Feyzi JM, Ivanovich P, Kewalramani R, Levey AS, Lewis EF, McGill JB, McMurray JJ, Parfrey P, Parving HH, Remuzzi G, Singh AK, Solomon SD, Toto R; TREAT Investigators. A trial of darbepoetin alfa in type 2 diabetes and chronic kidney disease. N Engl J Med 2009; 361: 2019-2032.
12. Ansell J, Hirsh J, Hylek E, Jacobson A, Crowther M, Palareti G. Pharmacology and management of the vitamin $\mathrm{K}$ antagonists: American College of Chest Physicians Evidence-Based Clinical Clin J Am Soc Nephrol 14: 278-287, February, 2019 Oral Anticoagulants in Kidney Disease, Jain et al. 285 Practice Guidelines 8th Edition. Chest 2008; 133 (6 Suppl): 160S-198S

13. Limdi NA, Beasley TM, Baird MF, Goldstein JA, McGwin G, Arnett DK, Acton RT, Allon M. Kidney function influences warfarin responsiveness and hemorrhagic complications. J Am Soc Nephrol 2009; 20: 912-921.

14. Solari F, Varacallo M. Low Molecular Weight Heparin (LMWH) [Updated 2019 Feb 1]. In: StatPearls [Internet]. Treasure Island (FL): StatPearls Publishing; 2019 Jan. Available from: https://www.ncbi.nlm.nih.gov/books/NBK525957/. Accessed March 20, 2019.

15. Pollack CV JR, Reilly PA, van Ryn J, Eikelboom JW, Glund S, Bernstein RA, Dubiel R, Huisman MV, Hylek EM, Kam CW, Kamphuisen PW, Kreuzer J, Levy JH, Royle G, Sellke FW, Stangier J, Steiner T, Verhamme P, Wang B, Young L, Weitz Jl. Idarucizumab for dabigatran reversal - full chort analysis. N Engl J Med 2017; 377: 2413-2424.

16. Siegal DM, Curnutte JT, Connolly SJ. Andexanet alfa for the reversal of factor Xa inhibitor activity. N Engl J Med 2015; 373: 2413-2424.

17. Huisman MV, Klok FA. Pharmacological properties of betrixaban. Eur Heart J 2018; 20 (Suppl E): E12-E15.

18. Weber, J, Olyaei A, Shatzel J. The efficacy and safety of direct oral anticoagulants in patients with chronic renal insufficiency: a review of the literature. Eur J Haematol 2019; 102: 312-318.

19. Lutz J, Jurk K, Schinzel H. Direct oral anticoagulants in patients with chronic kidney disease: patient selection and special considerations. Int J Nephrol Renovasc Dis 2017; 10: 135-143.

20. Lauffenburger JC, Farley JF, Gehi AK, Rhoney DH, Brookhart MA, Fang G. Effectiveness and safety of dabigatran and warfarin in real-world US patients with non-valvular atrial fibrillation: a retrospective cohort study. J Am Heart Assoc 2015; 4: pii: e001798.

21. Graham DJ, Reichman ME, Wernecke M, Zhang R, Southworth MR, Levenson M, Sheu TC, Mott K, Goulding MR, Houstoun M, MaCurdy TE, Worrall C, Kelman JA. Cardiovascular, bleeding, and mortality risks in elderly Medicare patients treated with dabigatran or warfarin for nonvalvular atrial fibrillation. Circulation 2015; 131: 157-164.

22. Romanelli RJ, Nolting L, Dolginsky M, Kym E, Orrico KB. Dabigatran versus warfarin for atrial fibriallation in real practice: a systemic review and metaanalysis. Circulation 2016; 9: 126-134.

23. Patel MR, Mahaffey KW, Garg J, Pan G, Singer DE, Hacke W, Breithardt G, Halperin JL, Hankey GJ, Piccini JP, Becker RC, Nessel CC, Paolini JF, Berkowitz SD, Fox KA, Califf RM; ROCKET AF Investigators. Rivaroxaban versus warfarin in nonvalvular atrial fibrillation. N Engl J Med 2011; 365: 883-891.

24. Jun M, Lix LM, Durand M, Dahl M, Paterson JM, Dormuth CR, Ernst P, Yao S, Renoux C, Tamim H, Wu C, Mahmud SM, Hemmelgarn BR; Canadian Network for Observational Drug Effect Studies (CNODES) Investigators. Comparative safety of direct oral anticoagulants and warfarin in venous thromboembolism: multicentre, population based, observational study. BMJ 2017; 359: j4323.

25. Samuelson BT, Cuker A, Siegal DM, Crowther M, Garcia DA. Laboratory assessment of the anticoagulant activity of direct oral anticoagulants: a sys tematic review. Chest 2017; 151: 127-138.

26. Adcock DM, Gosselin R. Direct oral anticoagulants (DOACs) in the laboratory Review. Thromb Res 2015; 136: 7-12.

27. Stangier J, Rathgen K, Stahle H, Mazur D. Influence of renal impairment on the pharmacokinetics and pharmacodynamics of oral dabigatran etexilate: an open-label, parallel-group, single-centre study. Clin Pharmacokinet 2010; 49: 259-268.

28. Lehr T, Haertter S, Liesenfeld KH, Staab A, Clemens A, Reilly PA, Friedman J. Dabibatran etexilate in atrial fibrillation patients with severe renal impairment: dose identification using pharmacokinetic modelling and simulation. J Clin Pharmacol 2012; 5299: 1373-1378.

29. Eikelboom JW, Wallentin L, Connolly SJ, Ezekowiz M, Healey JS, Oldgren J, Yang S, Alings M, Kaatz S, Hohnloser SH, Diener HC, Franzosi MG, Huber K, Reilly P, Varrone J, Yusuf S. Risk of bleeding with 2 doses of dabigatran compared with warfarin in older and younger patients with atrial fibrillation: an analysis of the randomized evaluation of long-term anticoagulant therapy (RE-LY) trial. Circulation 2011; 123: 2363-2372.

30. Hijazi Z, Hohnloser SH, Oldgren J, Andersson U, Connolly SJ, Eikelboom JW, Ezekowitz MD, Reilly PA, Siegbahn A, Yusuf S, Wallentin L. Efficacy and safety of dabigatran compared with warfarin in relation to baseline renal function in patients with atrial fibrillation: a RE-LY (Randomized Evaluation of Long-term Anticoagulation Therapy) trial analysis. Circulation 2014; 129: 961-970. 
31. Connolly SJ, Ezekowitz MD, Yusuf S, Eikelboom J, Oldgren J, Parekh A, Pogue J, Reilly PA, Themeles E, Varrone J, Wang S, Alings M, Xavier D, Zhu J, Diaz R, Lewis BS, Darius H, Diener HC, Joyner CD, Wallentin L; RE-LY Steering Committee and Investigators. Dabigatran versus warfarin in patients with atrial fibrillation. N Engl J Med 2009; 361: 1139-1151.

32. Granger CB, Alexander JH, McMurray JJV, Lopes RD, Hylek EM, Hanna M, AlKhalidi HR, Ansell J, Atar D, Avezum A, Bahit MC, Diaz R, Easton JD, Ezekowitz JA, Flaker G, Garcia D, Geraldes M, Gersh BJ, Golitsyn S, Goto S, Hermosillo AG, Hohnloser SH, Horowitz J, Mohan P, Jansky P, Lewis BS, LopezSendon JL, Pais P, Parkhomenko A, Verheugt FW, Zhu J, Wallentin L; ARISTOTLE Committees and Investigators. Apixaban versus warfarin in patients with atrial fibrillation. N Engl J Med 2011; 365: 981-992.

33. Coppens M, Synhorst D, Eikelboom JW, Yusuf S, Shestakovska O, Connolly SJ. Efficacy and safety of apixaban compared with aspirin in patients who previously tried and failed treatment with vitamin $\mathrm{K}$ antagonists: results from the AVERROES trial. Eur Heart 2014; 35: 1856-1863.

34. Wang X, Tirucherai G, Marbury TC, Wang J, Chang M, Zhang D, Song Y, Pursley J1, Boyd RA, Frost C. Pharmacokinetics, pharmacodynamics and safety of apixaban in subjects with end-stage renal disease on hemodialysis. J Clin Pharmacol 2016; 56: 628-636.

35. Chang M, Yu Z, Shenker A, Wang J, Pursley J, Byon W, Boyd RA, LaCreta F, Frost CE. Effect of renal impairment on the pharmacokinetics, pharmacodynamics, and safety of apixaban. J Clin Pharmacol 2016; 56: 637-645.
36. Giugliano RP, Ruff CT, Braunwald E, Murphy SA, Wiviott SD, Halperin JL, Waldo AL, Ezekowitz MD, Weitz JI, Špinar J, Ruzyllo W, Ruda M, Koretsune Y, Betcher J, Shi M, Grip LT, Patel SP, Patel I, Hanyok JJ, Mercuri M, Antman EM; ENGAGE AF-TIMI 48 Investigators. Edoxaban versus warfarin in patients with atrial fibrillation. N Engl J Med 2013; 369: 2093-2104.

37. Koretsune Y, Yamashita T, Kimura T, Fukuzawa M, Abe K, Yasaka M. Shortterm safety and plasma concentrations of edoxaban in Japanese patietns with non-valvular atrial fibrillation and severe renal impairment. Circ J 2015; 79: 1486-1495.

38. Parasrampuria DA, Marbury T, Matsushima N, Chen S, Wickremasingha PK, He L, Dishy V, Brown KS. Pharmacokinetics, safety, and tolerability of edoxaban in end-stage renal disease subjects undergoing haemodialysis. Thromb Haemost 2015; 113: 719-727.

39. Fox KA, Piccini JP, Wojdyla D, Becker RC, Halperin JL, Nessel CC, Paolini JF, Hankey GJ, Mahaffey KW, Patel MR, Singer DE, Califf RM. Prevention of stroke and systemic embolism with rivaroxaban compared with warfarin in patients with non-valvular atrial fibrillation and moderate renal impairment. Eur Heart J 2011; 32: 2387-2394.

40. De Vriese AS, Caluwe'R, Bailleul E, De Bacquer D, Borrey D, Van Vlem B, Vandecasteele SJ, Emmerechts J. Dose-finding study of rivaroxaban in hemodialysis patients. Am J Kidney Dis 2015; 66: 91-98. 